Original Research Paper

\title{
Differential Gene Transcription in Red Oak (Quercus rubra) Genotypes Resistant to Copper Toxicity
}

\author{
${ }^{1}$ Proulx Migueal, ${ }^{2}$ Paul Michael, ${ }^{2}$ Charnelle Djeukam and ${ }^{1,2}$ Kabwe Nkongolo \\ ${ }^{1}$ Department of Biology, Laurentian University, Sudbury, P3E 2C6, Ontario, Canada \\ ${ }^{2}$ Biomolecular Sciences Program, Laurentian University, Sudbury, P3E 2C6, Ontario, Canada
}

\author{
Article history \\ Received: 16-08-2017 \\ Revised: 14-11-2017 \\ Accepted: 11-12-2017 \\ Corresponding Author: \\ Kabwe Nkongolo \\ Department of Biology, \\ University of Sudbury, P3E \\ 2C6, Ontario, Canada \\ Email: knkongolo@laurentian.ca
}

\begin{abstract}
Toxicity of metals is a major abiotic stressor of plants. Copper $(\mathrm{Cu})$ is one of the most abundant metals in soils from the Greater Sudbury Region (GSR) due to its mining history. Recent studies have described several transporters and chelating proteins involved in copper resistance. Quercus rubra (Red Oak) is a common species that grows in metal contaminated soils in Northern Ontario (Canada). The main objectives of this study were1) to evaluate the toxicity of copper to Q. rubrum plants and 2) assess the level of transcriptionof genes associated with copper resistance (RAN1, MT2b and MRP4). Q. rubra seedlings were grown in growth chambers and treated with copper at different doses. Total RNA was extracted from leaves and amplified by RT-qPCR. All the plants tested were resistant to $\mathrm{Cu}$ even at high concentrations of $1312 \mathrm{mg}$ of $\mathrm{Cu}$ per $\mathrm{kg}$ of dry soil since no damage associated with $\mathrm{Cu}$ toxicity was observed after 14 days of treatment. RAN1 transporter and the chelating protein MT2b were significantly downregulated $(\mathrm{p} \leq 0.05)$ at high doses of $656 \mathrm{mg}$ and $1312 \mathrm{mg}$ of copper per $\mathrm{kg}$ of dry soil compared to water control. The transcription of MRP4 was significantly increased in the presence of copper at a concentration of $1312 \mathrm{mg} / \mathrm{kg}$. No gene demonstrated differential transcription in samples treated with a low dose of $130 \mathrm{mg}$ of copper $/ \mathrm{kg}$ of dry soil that is equivalent to the bioavailable amount of copper under natural conditions in the Greater Sudbury Region.
\end{abstract}

Keywords: Copper Toxicity, Red Oak (Quercus rubra), Gene Transcription, RT - qPCR, Northern Ontario

\section{Introduction}

Soil metal contamination is a serious problem for mining regions around the world. The Greater Sudbury Region (GSR), home to one of the world's largest copper and nickel mining operations (Winterhalder, 1995; Adamo et al., 2002), has been subject to mining since the end of 19th century (Belzile et al., 2004). These ongoing operations have resulted in higher levels of heavy metals such as copper and nickel in soils in this region (Adamo et al., 2002). Several studies have reported high concentrations of copper and nickel near smelters in the GSR compared to more remote areas (Narendrula et al., 2012; 2013). Although the amount of total metals in soil is high, recent studies have shown that it is essential to consider bioavailable metals to predict their toxicity and impact on vegetation (Violante et al., 2010; Abedin et al., 2012; Mehes-Smith et al., 2013). The bioavailable metals represent the potion of total elements that can be absorbed by the root system (Theriault and Nkongolo, 2016). Copper plays a role in the development and growth of several plant species (Yruela, 2005). It is a microelement that acts as a cofactor for several metalloproteins involved in various physiological processes such as electron transport in photosynthesis (Raven et al., 1999), mitochondrial respiration and cell membrane metabolism (Yruela, 2005).

At concentrations similar to the level found in soil from the GSR, copper has adverse effects on plants. It can impair plant growth and several cellular processes (Yruela, 2005). In the 1970s, the GSR had about 17,000 hectares of arid land and 72,000 semi-arid land near smelters (Winterhalder, 1995). Despite a significant reduction in metals and sulfur dioxide emissions, copper and nickel concentrations remain high. Yet the populations of several tree species in northern Ontario proliferate despite the high amount of metals in the ecosystem (Nkongolo et al., 2013; Tran et al., 2014; 
Theriault et al., 2014). Species such as red oak (Quercus rubra), some birch and poplar, recolonized metal contaminated areas within the GSR (Winterhalder, 1995; Makela et al., 2016). Q. rubra is a native species of GSR and has played an important role in the restoration process of this region (Beckett and Negusanti, 1990).

It is known that plants avoid the toxic effect of metals by maintaining a safe internal level (Manara, 2012). These protective physiological mechanisms vary greatly among species. Some species have developed a strategy to reduce the amount of bioavailable heavy metals by forming non-toxic metal complexes in the rhizosphere (Ryan et al., 2009; Maron et al., 2013). Other species try to avoid excessive absorption of heavy metals. This exclusion is based on a decrease in the transcription of genes coding for metal transporters in the root system resulting in a decrease in metal influx (Lin and Aarts, 2012). On the other hand, accumulators translocate metals in their aerial tissues (Baker, 1981). For example, copper accumulates in $Q$. rubra leaves at certain concentrations (Tran et al., 2014).

Genetic mechanisms involved in plant resistance to toxicity of metals are not well understood, especially in woody species such as $Q$. rubra. Several studies on model plant species and other non-model species have demonstrated that genes encode transporters (Sancenón et al., 2003; Keinänen et al., 2007; Kobayashi et al., 2008) and chelating proteins (Guo et al., 2008) which are associated with copper resistance. Some of the targeted genes, RAN1 and MRP4 code for ATPase transport protein families of the P-type (Yruela, 2005) and the ABC transporter (ATP Binding Cassette) (Rea, 1999; Keinänen et al., 2007), respectively for copper transport. Moreover, the selected MT2b gene codes for a protein of the metallothionein family which plays an important role in the chelation of metals (Guo et al., 2008). Some recent studies have demonstrated the link between these genes and copper resistance in some species and this coupled with the high survival of $Q$. rubra in metal contaminated sites in the GSR (Beckett and Negusanti, 1990; Adamo et al., 2002), leads us to hypothesize that resistance to the copper toxicity in $Q$. rubra might be mediated by RAN1, MRP4 and MT2b genes.

Hence, the main objectives of this study were to (1) evaluate the toxicity of copper to $Q$. rubrum plants and (2) assess the level of transcriptionof genes associated with copper resistance (RAN1, MT2b and MRP4).

\section{Materials and Methods}

\section{Samplings}

Quercus rubra seeds (seedlot\#007228) were collected from zone 34 in Southern Ontario, Canada (https://files.ontario.ca/seed_zones_of_ontario.jpg. The seedlings were germinated and grown in jiffy pots for five months. They were then transplanted in 50:50 mix of quartz sand and potting soil and acclimatized for a week before treatment.

To assess $\mathrm{Cu}$ toxicity on Q. rubra, six - month old seedlings were treated with different doses of copper. The copper treatments consisted of an aqueous solution of copper sulfate salt $\left(\mathrm{CuSO}_{4}\right)$ at final copper concentrations of $130 \mathrm{mg}, 656 \mathrm{mg}$ and $1312 \mathrm{mg}$ of copper per $\mathrm{kg}$ of dry soil. These levels corresponded to the bioavailable (fraction of the total copper available to biota), half total and total copper amounts in metalcontaminated soils within the GSR, respectively. To determine any potentially toxic effect of excess sulfate ion $\left(\mathrm{SO}_{4}\right)$ on plants, three potassium sulfate $\left(\mathrm{K}_{2} \mathrm{SO}_{4}\right)$ treatments corresponding to each $\mathrm{Cu}$ dose were included as controls. Salt-free water was used as the main control. The experimental design was a completely randomized block with 15 replications.

Copper toxicity was measured using a damage rating scale ranging from 1 to 9,1 being no visible toxicity symptoms and 9 dead plants. Individual plants with scores of 1 to 3 were considered copper resistant, 4 to 6 , moderately resistant and 7 to 9 susceptible. Plant heights were measured every two days throughout the experiment to measure the effects of each treatment on plant growth.

\section{RNA Extraction}

Total RNA was extracted from samples using the procedure described by Theriault and Nkongolo (2016; Djeukam et al., 2016). RNA was quantified using the Qubit RNA BR Assay kit from Life Technologies (Carlsbad, United States). RNA quality was verified on a $1 \%$ agarose gel. One microgram of RNA from samples of the same treatment was pooled together for further processing.

\section{$R T-q P C R$}

RNA was treated with DNase1 (\#EN0521) from Life Technologies. Sequences for each gene were retrieved from the NCBI database and analyzed by BLAST in the $Q$ rubra transcriptome described in "The Hardwood Genomics Project" (http://hardwoodgenomics.org). When possible, primers were designed to span all the exons encode by the genes. Primers were checked for hairpins, self and hetero-dimers using the OligoAnalyzer 3.1 by IDT (https://www.idtdna.com/calc/analyzer). The list of candidate genes with their associated primer pairs can be found in Table 1 and 2. The cDNA was synthesized using the High-Capacity cDNA Reverse Transcription Kit by Life Technologies.

PCR was performed on both Q. rubra DNA and cDNA. Size of the amplicons derived from primer pair amplification were verified on agarose gels. Only primers that showed a reproducible single band of the appropriate size were used for RT-qPCR. RT-qPCR was performed using the Dynamo HS SYBR Green Kit by Life Technologies according to the manufacturer's protocol. 
Table 1: Candidate genes involved in copper resistance in model and non-model plant species

\begin{tabular}{lll}
\hline Targeted genes & Species & References \\
\hline RAN 1 & Arabidopsis thaliana & Kobayashi et al. (2008) \\
MRP4 & Betula pendula & Keinänen et al. $(2007)$ \\
MT2b & Arabidopsis thaliana & Guo et al. (2008) \\
\hline
\end{tabular}

Table 2: Sequences of red oak (Quercus rubra) primers used for RT-qPCR and expected amplification product size

\begin{tabular}{llcc}
\hline $\begin{array}{l}\text { Targeted and } \\
\text { housekeeping gene }\end{array}$ & Primer pair sequences & Expected amplicon $(\mathrm{pb})$ & $\begin{array}{l}\text { Hybrization } \\
\text { tempearture }\left({ }^{\circ} \mathrm{C}\right)\end{array}$ \\
\hline $\begin{array}{l}\text { Targeted gene } \\
\text { RAN 1 }\end{array}$ & $\begin{array}{l}\text { F: TGCTTGCTCCAATTCTGTTG } \\
\text { R: AGAGCTCCATGTGGCTTTGT }\end{array}$ & 210 & 55 \\
MT2b & $\begin{array}{l}\text { F: GGAAACTGTGGCTGTGGAAC } \\
\text { R: CTGAGGAGCAACACCAACAA }\end{array}$ & 123 & 55 \\
MRP4 & $\begin{array}{l}\text { F: TTGTTGGGACTGTGGGATCT } \\
\text { R: TGGTGCCATTTTGTAATCCA }\end{array}$ & 139 & 55 \\
House keeping gene & F: GACGTGTCTGTGCTCTTGGA & 147 & 55 \\
\hline -tubuline & R: AGCCCCATCAAATCTCAATG & & \\
\hline
\end{tabular}

Each sample was amplified with the MJ Research PTC200 Thermal Cycler in triplicates. The process included (1) initial denaturing at $95^{\circ} \mathrm{C}$ for $15 \mathrm{~min}$; (2) denaturing at $94^{\circ} \mathrm{C}$ for $30 \mathrm{sec}$; (3) $30 \mathrm{sec}$ at $55^{\circ} \mathrm{C}$ annealing; (4) elongation at $72^{\circ} \mathrm{C}$ for $30 \mathrm{sec}$; (5) read (6) repeat step 2-6 for 41 cycles; (7) final elongation at $72^{\circ} \mathrm{C}$ for $7 \mathrm{~min}$; (8) melting curve $72-95^{\circ} \mathrm{C}$, every $1^{\circ} \mathrm{C}$, hold for $10 \mathrm{sec}$; and (9) final elongation at $72^{\circ} \mathrm{C}$ for $3 \mathrm{~min}$. This $\mathrm{qPCR}$, was run three separate times with each sample in triplicate. This resulted in a total of nine data point for each bulked sample.

The data was analyzed using the MJ Opticon Monitor 3.1 by BioRad and delta $C(t)$ values were exported to excel. Delta $C(t)$ values of samples from growth chamber assays were normalized to a separate housekeeping gene and the relative transcription was calculated using the water control.

\section{Statistical Analysis}

Data were analyzed using SPSS 20 for Windows, with all data being transformed to achieve a normal distribution. ANOVA, followed by Dunnett T3 were performed to determine significant differences among means. Student $\mathrm{T}$ test was performed to determine significant differences between gene transcription levels for different $\mathrm{CuSO}_{4}$ treatments and the controls. All the differences were determined at $\mathrm{p} \leq 0.05$.

\section{Results}

\section{Copper Toxicity}

Analysis of damage ratings and plant growth revealed no significant difference among the treatments during the 14 days of the assays. All the seedlings treated showed no symptoms of copper toxicity even at the highest concentration of $1,312 \mathrm{mg} / \mathrm{kg}$ for 14 days (Table 3 ).

\section{Gene Transcription}

All the primer pairs developed for the targeted genes were functional for qRT-PCR analysis since they generated expected size amplifications. Analysis of qRTPCR data showed that transcription of two genes (RAN1 and MT2b) were significantly decreased demonstrated a compared to controls for 656 and $1312 \mathrm{mg} \mathrm{Cu} / \mathrm{kg}$ treatment while MRP4 transcription was increased only at the dosage of $1,312 \mathrm{mg} / \mathrm{kg}$.

Sulfates at the three concentrations tested had no effect on gene transcription. Detailed data on plant reaction to sulfate are summarized in Fig. 1S and 2S. RNA1 gene was significantly suppressed by copper treatments at $1,312 \mathrm{mg} / \mathrm{kg}$ and $656 \mathrm{mg} / \mathrm{kg}$ compared to their respective water and potassium sulfate control treatments (Fig. 1 and 1S) but not between treatment of $1,312 \mathrm{mg} / \mathrm{kg}$ and $656 \mathrm{mg} / \mathrm{kg}$ (Fig. 1). The same result was observed when the $130 \mathrm{mg} / \mathrm{kg}$ treatment was compared to water control (Fig. 1).

No significant difference in transcription was observed between sulfate and water controls (Fig. 2S). Significant down regulation (suppression) of the MT2b gene was observed for high copper treatments (656 $\mathrm{mg} / \mathrm{kg}$ and $1,312 \mathrm{mg} / \mathrm{kg}$ ) compared to the respective water and sulfate control treatments $(\mathrm{p} \leq 0.05)$ (Fig. 2 and $2 \mathrm{~S})$. No significant difference was observed between $1,312 \mathrm{mg} / \mathrm{kg}$ and $656 \mathrm{mg} / \mathrm{kg}$ treatments (Fig. 2). Similarly, the level of transcription of MT2b gene was similar when $130 \mathrm{mg} / \mathrm{kg}$ treatment was compared with water control (Fig. 2).

On the other hand, MRP4 was significantly upregulated at the high dose of $1312 \mathrm{mg}$ of copper $/ \mathrm{kg}$ of dry soil compared to water and sulfate controls (Fig. 3 and 3S). Similarly, at this dose, Copper treatments at 130 $\mathrm{mg} / \mathrm{kg}$ and $656 \mathrm{mg} / \mathrm{kg}$ did not result in significant differences in transcription with their respective water and sulfate control (Fig. 3 and Fig. 3S). 
Table 3: Damage ratings of Quercus rubra seedlings after 14 days of treatments with different doses of copper sulfate $\left(\mathrm{CuSO}_{4}\right)$ and potassium sulfate $\left(\mathrm{K}_{2} \mathrm{SO}_{4}\right)$

\begin{tabular}{llll}
\hline Treatments & Copper Concentrations $(\mathrm{mg} / \mathrm{kg})$ & $\mathrm{SO}_{4}{ }^{2-}$ Concentration $(\mathrm{mg} / \mathrm{kg})$ & Damage rating \\
\hline $\mathrm{CuSO}_{4}$ & 130 & 0.20 & $1.1 \pm 0.1$ \\
& 656 & 0.99 & $1.0 \pm 0.0$ \\
& 1312 & $2.0 \pm 0.4$ & $1.0 \pm 0.0$ \\
$\mathrm{~K}_{2} \mathrm{SO}_{4}$ & 1.98 & 0.20 & $1.0 \pm 0.0$ \\
& 0 & 0.99 & \\
& 0 & $1.4 \pm 0.4$ & $1.0 \pm 0.0$ \\
Water & 0 & 0 & 0.0 \\
\hline
\end{tabular}

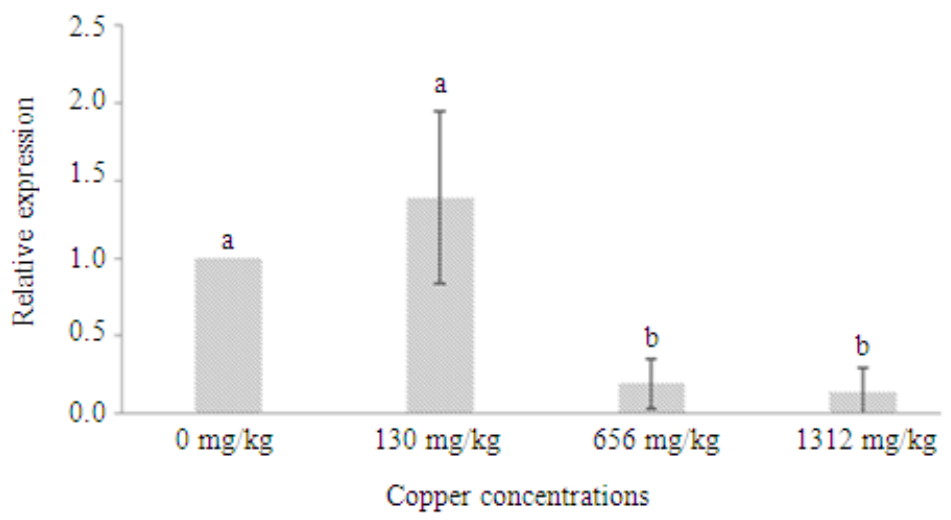

Fig. 1: Transcription of RAN1 in red oak (Quercus rubra) treated with different doses of copper. Transcription of RAN1 was standardized based on the housekeeping gene $\alpha$-tubulin 1. Significant differences were found among treatments based on ANOVA and Dunnett T3 tests. Means with different letters are significantly different $(\mathrm{p}<0.05)$

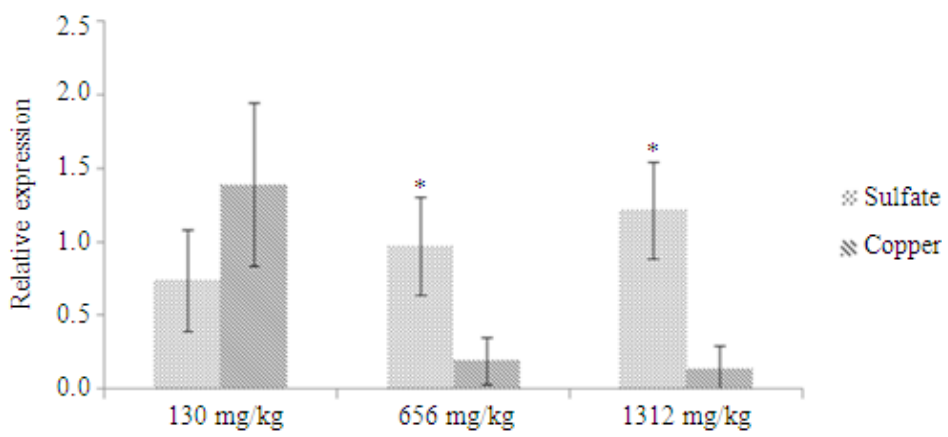

(a)

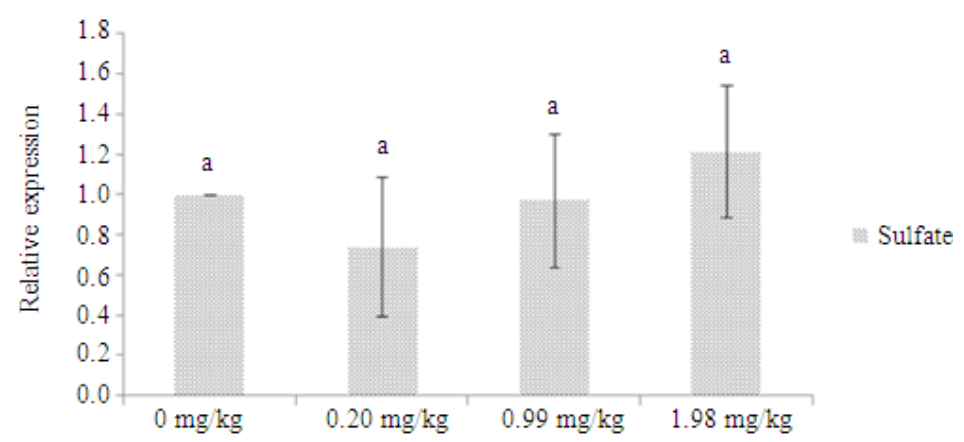

(b)

Fig. 1S: Transcription of RAN1 in red oak (Quercus rubra) treated with different doses of copper: (a) treatments with $130 \mathrm{mg} / \mathrm{kg}, 656$ $\mathrm{mg} / \mathrm{kg}$ and $1312 \mathrm{mg} / \mathrm{kg}$ with respective sulfate controls $(0.20,0.99$ and $1.98 \mathrm{mg} / \mathrm{kg}) ; \mathrm{b})$ treatments with sulfate and water controls. Transcription of RAN1 was standardized based on the housekeeping gene $\alpha$-tubulin 1 . Significant differences were found among treatments based on ANOVA and Dunnett T3 tests. Means with different letters are significantly different $(\mathrm{p}<0.05)$ 


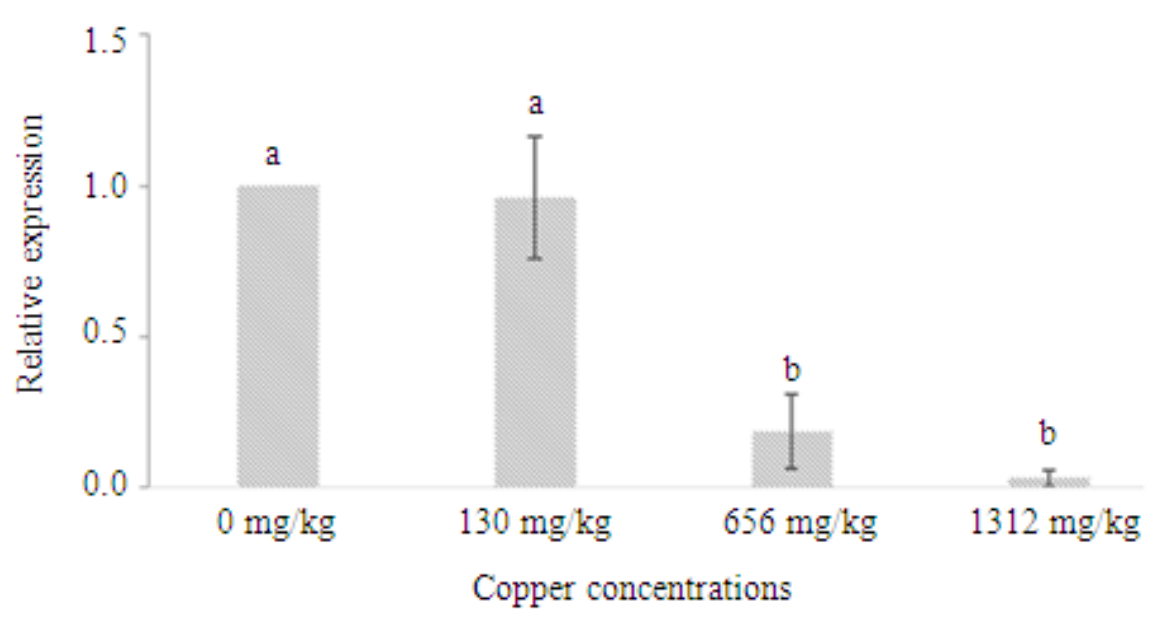

Fig. 2: Transcription of MT2b in red oak (Quercus rubra) treated with different doses of copper. Transcription of MT2b was standardized based on the housekeeping gene $\alpha$-tubulin 1. Significant differences were found among treatments based on ANOVA and Dunnett T3 tests. Means with different letters are significantly different $(\mathrm{p}<0.05)$

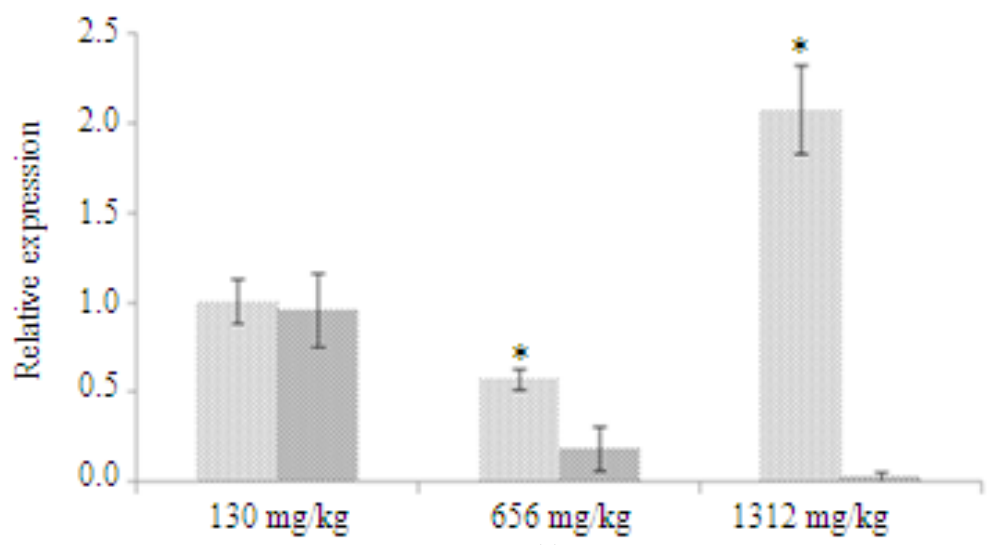

Sulfate

ECopper

(a)

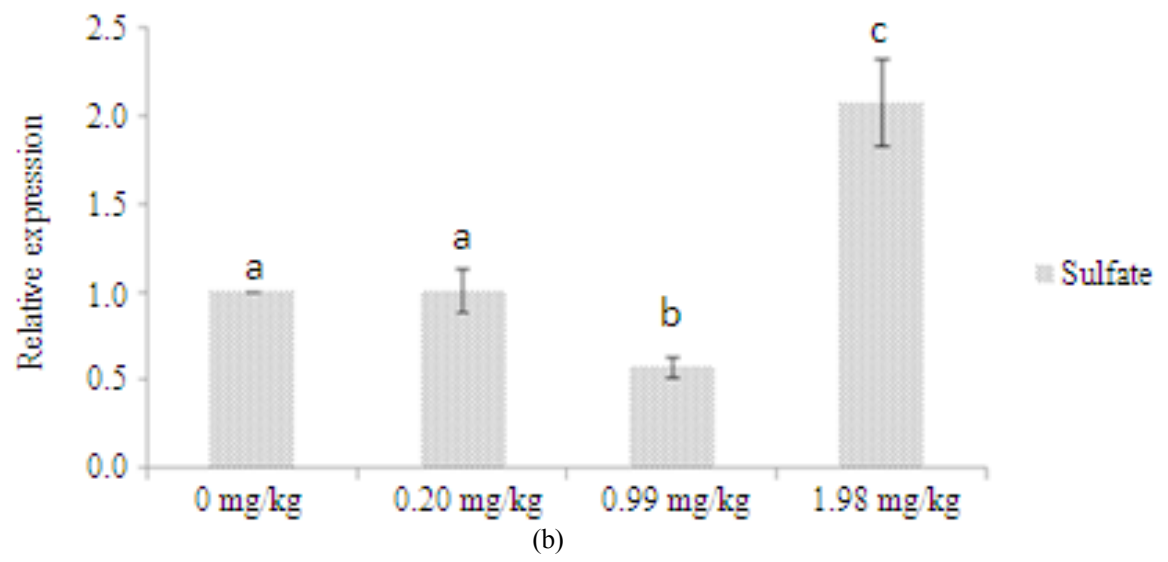

Fig. 2S: Transcription of MT2b in red oak (Quercus rubra) treated with different doses of copper: (a) treatments with 130 $\mathrm{mg} / \mathrm{kg}, 656 \mathrm{mg} / \mathrm{kg}$ and $1312 \mathrm{mg} / \mathrm{kg}$ with respective sulfate controls $(0.20,0.99$ and $1.98 \mathrm{mg} / \mathrm{kg})$; (b) treatments with sulfate and water controls. Transcription of MT2b was standardized based on the housekeeping gene $\alpha$-tubulin 1 . Significant differences were found among treatments based on ANOVA and Dunnett T3 tests. Means with different letters are significantly different $(\mathrm{p}<0.05)$ 


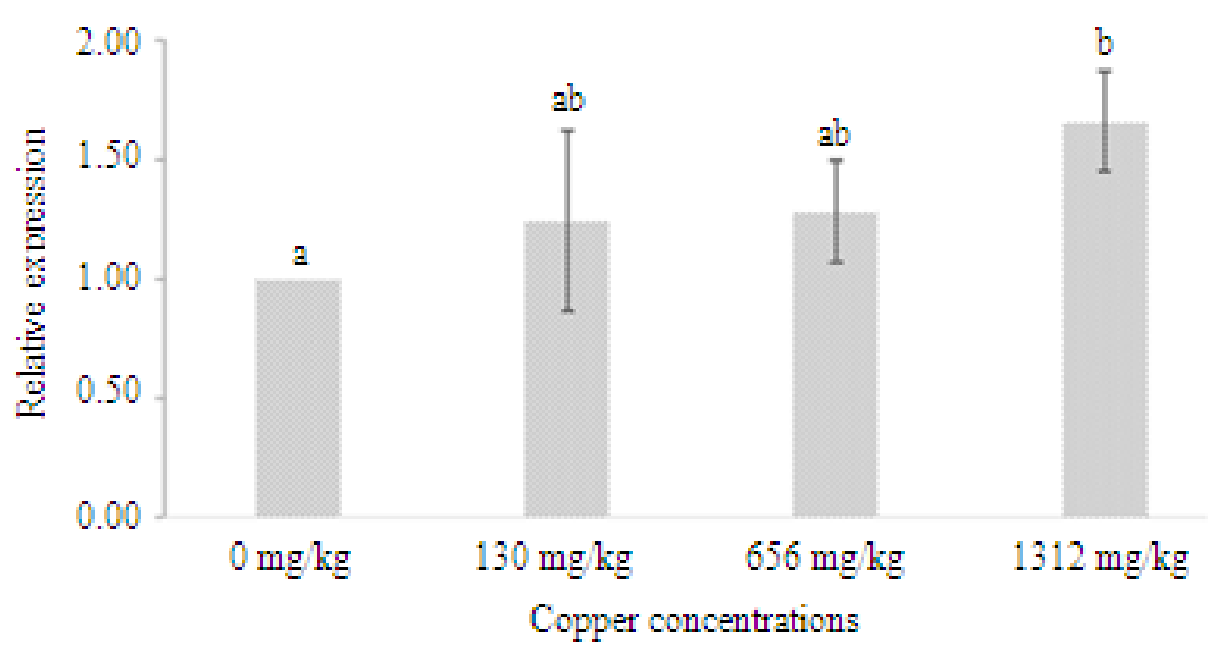

Fig. 3: Transcription of MRP4 in red oak (Quercus rubra) treated with different doses of copper. Transcription of MRP4 was standardized based on the housekeeping gene $\alpha$-tubulin 1 . Significant differences were found among treatments based on ANOVA and Dunnett T3 tests. Means with different letters are significantly different $(\mathrm{p}<0.05)$

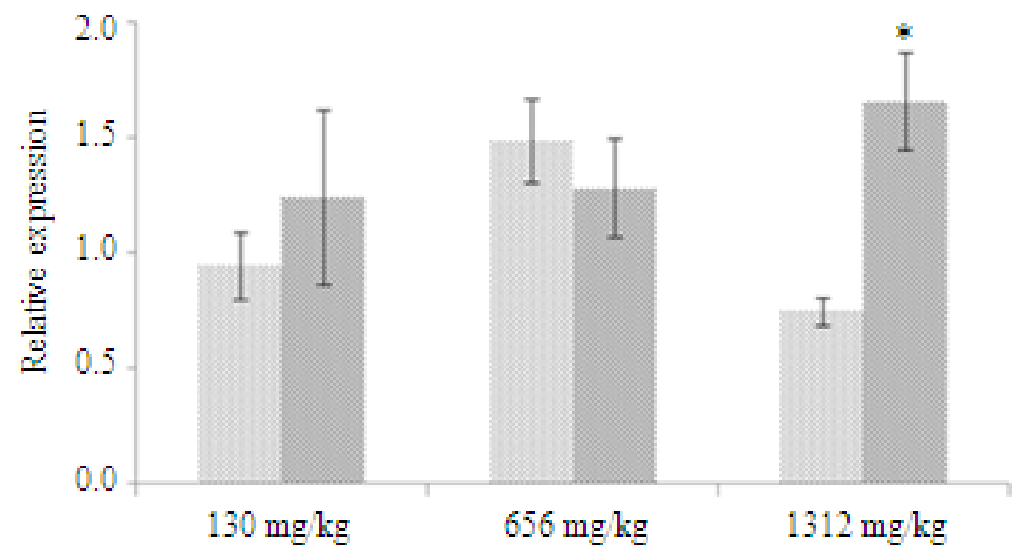

(a)
8 Sulfate

Copper

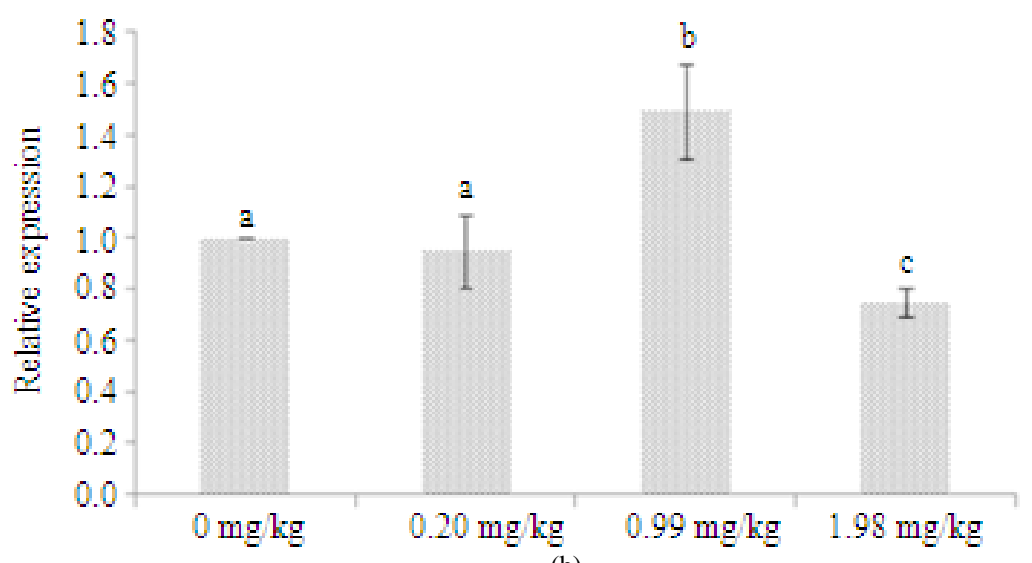

(b)

Fig. 3S: Transcription of MRP4 in red oak (Quercus rubra) treated with different doses of copper (a) treatments with $130 \mathrm{mg} / \mathrm{kg}$, $656 \mathrm{mg} / \mathrm{kg}$ and $1312 \mathrm{mg} / \mathrm{kg}$ with respective sulfate controls $(0.20,0.99$ and $1.98 \mathrm{mg} / \mathrm{kg})$ (b) treatments with sulfate and water controls. Transcription of MRP4 was standardized based on the housekeeping gene $\alpha$-tubulin 1 . Significant differences were found among treatments based on ANOVA and Dunnett T3 tests. Means with different letters are significantly different $(\mathrm{p} \leq 0.05)$ 


\section{Discussion}

\section{Importance of Multiple Controls}

Plant root systems absorb only solubilized and bioavailable forms of metals in soil. In the present study, copper sulfate $\left(\mathrm{CuSO}_{4}\right)$ was the salt used in copper treatments because of its high solubility that enables it to ionize to $\mathrm{Cu}^{+2}$ and $\mathrm{SO}_{4}{ }^{-2}$ when mixed in water. Thus, solubilized copper is available for assimilation by $Q$. rubra roots. However, the second component of the solubilized salt, the sulfate ion, is also absorbed by the roots and can cause adverse effects to plants at high concentrations as demonstrated by Djeukam et al. (2016). Indeed they showed the adverse effects of potassium sulfateon another woody species (Betula papyrifera) that was associated with an increase in concentrations (Djeukam et al., 2016). Therefore, it is important to consider the potential effects of this ion on phenotypic damage and gene transcription change, even at low concentrations. Surprisingly, in this study, no significant differences were found between the control treatments for the sulfate ion $\left(\mathrm{K}_{2} \mathrm{SO}_{4}\right)$ and the water control based on the level of damage to plants and their growth.

\section{Copper Toxicity}

Copper is an essential microelement that is toxic toplants in large amounts (Wuana and Okieimen, 2011). A wide range of studies have shown that an excess of copper has the potential to be toxic and result in several physical symptoms in several plant species (Adrees et al., 2015). Specifically, it can induce several symptoms such as chlorosis (Ali et al., 2002; Shahbaz et al., 2010; Feigl et al., 2013), necrosis (Drazkiewicz et al., 2004; Yruela, 2009; Foy et al., 1978; Barbosa et al., 2013; Aly and Mohamed, 2012) and inhibition of root and aerial plant tissue growth (Ali et al., 2002; Benimeli et al., 2010; Cook et al., 1997). In addition, recent studies have demonstrated the presence of such symptoms in woody plant species (Theriault and Nkongolo, 2016; Djeukam et al., 2016). It is therefore essential for plants to develop a mechanism to regulate copper homeostasis.

A recent study has shown that copper is found in $Q$. rubra leaves in GSR (Tran et al., 2014) where it can cause oxidative stress (Drazkiewicz et al., 2004) and a decreased chlorophyll concentration (chlorosis) (Pätsikkä et al., 2002; Feigl et al., 2013). In this study, a damage score was assigned to plants based on the percentage of leaf area covered by chlorosis and/or necrosis (Table 1). But, no significant differences among the different treatments for plant damage were observed. Thus, copper at the concentrations used in this study $(130-1312 \mathrm{mg} / \mathrm{kg}$ ) does not cause symptoms of oxidative stress such as chlorosis and necrosis in Q. rubra leaves. Many other studies have shown a reduction in plant growth in the presence of high copper concentrations.
For example, Benimeli et al. (2010), as well as Barbosa et al. (2013), observed a decrease of Zea mays plants in the presence of high concentrations of copper. The same effects were observed in other species such as Brassica juncea, Brassica napus (Feigl et al., 2013) and Triticum aestivum (Cook et al., 1997). Djeukam et al. (2016) observed a reduction in the growth of $B$. papyrifera seedlings treated with copper at a concentration dose of $1312 \mathrm{mg} / \mathrm{kg}$ or more compared to a water control. In this study, growth of $Q$. rubra plants was not significantly affected by $\mathrm{Cu}$ at all the doses used $(130,656$ and $1312 \mathrm{mg} / \mathrm{kg})$ and their respective control treatments.

Our results also contrast with data from other studies that focused on B. papyrifera (a hard wood species) showing a decrease in growth and the presence of leaf chlorosis and necrosis after exposure to copper (Djeukam et al., 2016) and nickel (Theriault and Nkongolo, 2016). However, Keller et al. (2003) suggests that the root system surface may have an impact in the absorption of metals such as copper and potentially lead to a difference in assimilation of metals between these species (Keller et al., 2003). This difference in species copper assimilation needs further study.

\section{Effect of Copper on Gene Regulation}

A toxic amount of copper and other metals associate with oxidative stress, the production of Reactive Oxygen Species (ROS) (Drazkiewicz et al., 2004). Damage to plants can be induced by copper directly or by the ROS that it has formed. ROS can denature proteins, create mutations in DNA and cause membrane instability by lipid peroxidation (Salin, 1988; Bowler et al., 1992; Scandalios, 1993; Yadav, 2010). Some plant cells have therefore developed defense systems that protect them against ROS damage (Drazkiewicz et al., 2004). Other plants have instead developed mechanisms to regulate copper absorption and intracellular distribution by using metal transporters. Some transporters such as the COPT and ZIP families transport copper intracellularly (Burkhead et al., 2009) and then through internal membranes to organelles using transporters known as ATPases for Heavy Metals (HMA) (Baloun et al., 2014). At present, eight transporters of the HMA family (HMA1-8) have been identified in A. thaliana. HMA1-4 has been identified as playing a role in the transport of zinc, cadmium and lead, while HMA5-8 transports silver and copper. A specific transporter of this family, HMA7 (also called RAN1 (responsive to antagonist 1) plays a role in the transmembrane transport of copper at the cytosol level to the Golgi apparatus (Woeste and Kieber, 2000).

More specifically, Baloun et al. (2014) identified the presence of the RAN1 gene in two ecotypes of the species Silene vulgaris, one being tolerant to copper and the second susceptible. A significant increase in RAN1 
expression was observed in copper-tolerant plants (Baloun et al., 2014) and an increase in expression was observed in the presence of excess copper in all plants. A homologous gene (HMA5) of RAN1 has a very similar DNA sequence (Yruela, 2005) is involved in copper resistance in $A$. thaliana (Kobayashi et al., 2008). On the other hand, Del Pozo et al. (2010) observed a suppression of RAN1 in aerial parts of $A$. thaliana exposed to copper. In this study, significant suppression of the RAN1 gene was observed in $Q$. rubra exposed to high copper doses (656 and $1312 \mathrm{mg} / \mathrm{kg}$ ) compared to controls (Fig. 2a). The different expression of the RAN1 gene in different species suggest that the mechanisms of resistance to copper developed by plants vary from one species to another.

Chelation by a metal ligand is another mechanism of detoxification of an excessive amount of essential metals (copper, for example). Metallothioneins (MTs) are cysteine-rich proteins found in the cytoplasm of cells of a wide variety of organisms such as animals, microorganisms and plants (van Hoof et al., 2001). There is evidence that MTs play a role in protecting plants against the harmful effects of copper by chelation making the excess copper unavailable to activate (van Hoof et al., 2001; Guo et al., 2008). The implication of MTs in metal resistance is attributed to the presence its cysteine residues. Some studies have demonstrated their implications in the detoxification of copper in Saccharomyces cerevisiae (Ecker et al., 1989). A copper-sensitive yeast colony was transformed with the Silene vulgaris MT2b gene, which conferred copper tolerance Other studies have shown that plants tolerant to copper have a greater expression of the MT2b gene in Silene vulgaris (van Hoof et al., 2001) and Silene paradoxa (Mengoni et al., 2003), whereas we observed a significant suppression of this gene in $Q$. rubra at high concentrations of copper compared with sulfate and water controls. However, the two studies involve different tissues (roots or leaves) in different species and it is not clear whether the transcription of MT2b is increased in Q. rubra roots exposed to copper. For example, copper treatment with $A$. thaliana increases the expression of MT2b in roots (Guo et al., 2003). Other studies have shown that Silene vulgaris (van Hoof et al., 2001) and Silene paradoxa (Mengoni et al., 2003) populations that are tolerant to copper have a greater expression of the MT2b gene. But, in the present study a significant suppression of this gene was observed in $Q$. rubra in the presence of high concentrations of copper (656 and $1312 \mathrm{mg} / \mathrm{kg}$ ) compared with their respective control treatments of sulfate and water control. However, the two studies are not similar since they involve different tissues (roots and leaves) in different species. Thus, it would be interesting to observe the expression of MT2b in Q. rubra roots exposed to $\mathrm{Cu}$.

Proteins associated with Multidrug ResistanceAssociated Proteins (MRPs) belong to the ABC transporter family (Rea, 1999). Through energy (ATP), this family of proteins transports several substances such as amino acids, lipids, sugars and chelated metals (Rea, 1999). These transporters play an integral role in the detoxification of plants. It has been suggested that one of its potential functions is the vacuolar sequestration of toxic elements (e.g., heavy metals). But the precise role of these transporters in woody species such as $Q$. rubra remains unknown. Bovet et al. (2003) reported an increase in expression of several genes encoding MRPs in response to cadmium exposure in A. thaliana. In addition, Keinänen et al. (2007) compared copperresistant and susceptible birch (Betula pendula) and revealed differential transcription of the MRP4 gene.

Indeed, a high increase in the transcription of the MRP4 gene has been observed in copper-resistant $B$. pendula in the presence of a high level of this metal (Keinänen et al., 2007). In the present study, no significant difference was found between MRP4 gene transcriptionin plants treated with $656 \mathrm{mg}$ and $130 \mathrm{mg}$ of $\mathrm{Cu}$ per $\mathrm{kg}$ of soil compared to their respective control treatments. However, treatment of copper at a dose of $1,312 \mathrm{mg} / \mathrm{kg}$ resulted in a significant increase in transcription of this gene compared with control. Thus, copper tolerance in Q. rubra appears to be partially mediated by this gene when copper concentration in soil is greater than $1,312 \mathrm{mg} / \mathrm{kg}$. Keinänen et al. (2007) demonstrated that the increase in MRP4 gene transcription was at the level of the root system and the stem. Similarly, the increased transcription of MRP4 in the presence of cadmium was evident at the root level (Bovet et al., 2003). Since the RNA in this study was extracted from $Q$. rubra leaves and not from roots or stems, it is difficult to compare the results with those of other authors. Therefore, future studies should focus on evaluating the transcription of the MRP4 gene in these different tissues.

\section{Conclusion}

In this study, an analysis of plant damage and growth changes in response to copper contamination was performed. No significant differences were found among treatments based on damage rating and plant growth. An analysis of the genes playing a role in copper resistance in other species was carried out to determine whether they associate with this phenomenon in $Q$. rubra. The study revealed that the transcription of each targeted gene is affected by the highest copper dose and supports the hypothesis that RAN1, MT2b and MRP4 are involved in the copper resistance in $Q$. rubra. On the other hand, this reinforces the fact that the bioavailable copper in metalcontaminated soils from the GSR are therefore insufficient to induce a genetic response in $Q$. rubra

\section{Acknowledgement}

We would like to thank the Natural Sciences and Engineering Research Council of Canada (NSERC) for 
financial support. We also thank Mr. Marc Hebert from College Boreal, Sudbury, Ontario for providing red oak seeds used in this study.

\section{Author's Contributions}

Proulx Migueal: Corrducted research, analyzed the data and revised the mamuscript.

Paul Michael: Monitored research experiments and data analysis.

Charnelle Djeukam: Assisted with molecular analysis and data analysis.

Kabwe Nkongolo: Designed the experiments, coordinated research activities and wrote the manuscript.

\section{Conflict of Interest}

The authors declare no conflict of interest.

\section{References}

Abedin, J., P. Beckett and G. Spiers. 2012. An evaluation of extractants for assessment of metal phytoavailability to guide reclamation practices in acidic soilscapes in northern regions. Canadian J. Soil Sci., 92: 253-268. DOI: 10.4141/cjss2010-061

Adamo, P., S. Dudka, M.J. Wilson and W.J. McHardy. 2002. Distribution of trace elements in soils from the sudbury smelting area (Ontario, Canada). Water, Air Soil Pollut., 137: 95-116.

DOI: $10.1023 / \mathrm{A}: 1015587030426$

Adrees, M., S. Ali, M. Rizwan, M. Ibrahim and F. Abbas et al., 2015. The effect of excess copper on growth and physiology of important food crops: A review. Environ. Sci. Pollut. Res., 22: 8148-8162. DOI: $10.1007 / \mathrm{s} 11356-015-4496-5$

Ali, N.A., M.P. Bernal and M. Ater, 2002. Tolerance and bioaccumulation of copper in Phragmites australis and Zea mays. Plant Soil, 239: 103-111.

DOI: $10.1023 / \mathrm{A}: 1014995321560$

Aly, A.A. and A.A. Mohamed, 2012. The impact of copper ion on growth, thiol compounds and lipid peroxidation in two maize cultivars (Zea Mays L.) Grown in vitro. Aus. J. Crop Sci., 6: 541-549.

Baker, A.J.M., 1981. Accumulators and excludersstrategies in the response of plants to heavy metals. J. Plant Nutrition, 3: 643-654. DOI: $10.1080 / 01904168109362867$

Baloun, J., E. Nevrtalova, V. Kovacova, V. Hudzieczek and R. Cegan et al., 2014. Characterization of the HMA7 gene and transcriptomic analysis of candidate genes for copper tolerance in two Silene vulgaris ecotypes. J. Plant Physiol., 171: 1188-1196.

DOI: 10.1016/j.jplph.2014.04.014
Barbosa, R.H., L.A. Tabaldi, F.R. Miyazaki, M. Pilecco and S.O. Kassab et al., 2013. Foliar copper uptake by maize plants: Effects on growth and yield. Ciiencia Rural, 43: 1561-1568. DOI: $10.1590 / \mathrm{S} 0103-84782013000900005$

Beckett, P.J. and J. Negusanti, 1990. Using Land Reclamation Practices to Improve Tree Condition in the Sudbury Smelting Area, Ontario Canada. In: Mining and Reclamation Conference and Exhibition, Skousen, E.J., J. Sencindiver and D. Samuel (Edn.), West Virginia: West Virginia University Publication Services, Morgantown, pp: 307-320.

Belzile, N., Y.W. Chen, J.M. Gunn and S.S. Dixit, 2004. Sediment trace metal profiles in lakes of Killarney park, Canada: From regional to continental influence. Environ. Pollut., 130: 239-248.

DOI: $10.1016 /$ j.envpol.2003.12.003

Benimeli, C.S., A. Medina, C.M. Navarro, R.B. Medina and M.J. Amoroso et al., 2010. Bioaccumulation of copper by Zea mays: Impact on root, shoot and leaf growth. Water, Air Soil Pollut., 210: 365-370. DOI: $10.1007 / \mathrm{s} 11270-009-0259-6$

Bovet, L., T. Eggmann, M. Meylan-Bettex, J. Polier and P. Kammer et al., 2003. Transcript levels of AtMRPs after cadmium treatment: Induction of AtMRP3. Plant, Cell Environ., 26: 371-381. DOI: 10.1046/j.1365-3040.2003.00968.x

Bowler, C., M.V. Montagu and D. Inze, 1992. Superoxide dismutase and stress tolerance. Annual Rev. Plant Physiol. Plant Molecular Biol., 43: 83116. DOI: 10.1146/annurev.pp.43.060192.000503

Burkhead, J.L., K.A.G. Reynolds, S.E. Abdel-Ghany and C.M. Cohu et al., 2009. Copper homeostasis. New Phytol., 182: 799-816.

DOI: $10.1111 /$ j.1469-8137.2009.02846.x

Cook, C.M., E. Vardaka and T. Lanaras, 1997. Concentrations $\mathrm{OF} \mathrm{Cu}$, growth and chlorophyll content of field- cultivated wheat growing in naturally enriched $\mathrm{Cu}$ soil. Bull. Environ. Contamination Toxicol., 58: 248-253.

DOI: $10.1007 / \mathrm{s} 001289900327$

Del Pozo, T., V. Cambiazo and M. González, 2010. Gene expression profiling analysis of copper homeostasis in Arabidopsis thaliana. Biochem. Biophys. Res. Commun., 393: 248-252.

DOI: $10.1016 /$ j.bbrc.2010.01.111

Djeukam, C., G. Theriault, P. Michael and K. Nkongolo, 2016. Analysis of gene expression associated with copper toxicity in white birch (Betula papyrifera) populations from a mining region. Br. Biotechnol. J., 15: 1-10. DOI: 10.9734/BBJ/2016/28425

Drazkiewicz, M., E. Skórzynska-Polit and Z. Krupa, 2004. Copper-induced oxidative stress and antioxidant defence in Arabidopsis thaliana. Biometals, 17: 379-387. DOI: 10.1023/B:BIOM.0000029417.18154.22 
Ecker, D.J., T.R. Butt and S.T. Crooke, 1989. Yeast Metallothionein - Gene-Function and Regulation by Metal-Ions. In: Metal Ions in Biological Systems, Sigel, A. and H. Sigel (Eds.), pp: 147-169.

Feigl, G., D. Kumar, N. Lehotai, N. Tugyi and Á. Molnár et al., 2013. Physiological and morphological responses of the root system of Indian mustard (Brassica juncea L. Czern.) and rapeseed (Brassica napus L.) to copper stress. Ecotoxicol. Environ. Safety, 94: 179-189. DOI: 10.1016/j.ecoenv.2013.04.029.

Foy, C.D., R.L. Chaney and M.C. White, 1978. The physiology of metal toxicity in plants. Annual Revi. Plant Physiol., 29: 511-566. DOI: 10.1146/annurev.pp.29.060178.002455

Guo, W., M. Meetam and P.B. Goldsbrough, 2008. Examining the specific contributions of individual arabidopsis metallothioneins to copper distribution and metal tolerance. Plant Physiol., 146: 1697-1706. DOI: $10.1104 / p p .108 .115782$

Guo, W.J., W. Bundithya and P.B. Goldsbrough, 2003. Characterization of the arabidopsis metallothionein gene family: Tissue-specific expression and induction during senescence and in response to copper. New Phytologist, 159: 369-381. DOI: 10.1046/j.1469-8137.2003.00813.x

Keinänen, S.I., V.H. Hassinen, S.O. Kärenlampi and A.I. Tervahauta, 2007. Isolation of genes up-regulated by copper in a copper-tolerant birch (Betula pendula) clone. Tree Physiol., 27: 1243-1252.

DOI: $10.1093 /$ treephys/27.9.1243

Keller, C., D. Hammer, A. Kayser, W. Richner and M. Brodbeck et al., 2003. Root development and heavy metal phytoextraction efficiency: Comparison of different plant species in the field. Plant Soil, 249: 67-81. DOI: 10.1023/A:1022590609042

Kobayashi, Y., K. Kuroda, K. Kimura, J.L. SouthronFrancis and A. Furuzawa et al., 2008. Amino acid polymorphisms in strictly conserved domains of a PType ATPase HMA5 are involved in the mechanism of copper tolerance variation in Arabidopsis. Plant Physiol., 148: 969-980. DOI: 10.1104/pp.108.119933

Lin, Y.F. and M.G.M. Aarts, 2012. The molecular mechanism of zinc and cadmium stress response in plants. Cellular Molecular Life Sci., 69: 3187-3206. DOI: $10.1007 / \mathrm{s} 00018-012-1089-\mathrm{z}$

Makela, M., P. Michael, G. Theriault and K.K. Nkongolo, 2016. High genetic variation among closely related red oak (Quercus rubra) populations in an ecosystem under metal stress: Analysis of gene regulation. Genes Genom., 38: 967-976.

DOI: $10.1007 / \mathrm{s} 13258-016-0441-3$

Manara, A., 2012. Plant Responses to Heavy Metal Toxicity. In: Plants and Heavy Metals, Furini, A. (Ed.), Springer Netherlands, pp: 27-53.
Maron, L.G., C.T. Guimarães, M. Kirst, P.S. Albert and J.A. Birchler et al., 2013. Aluminum tolerance in maize is associated with higher MATE1 gene copy number. Proceedings of the National Academy of Sciences, (NAS'13), USA, pp: 5241-5246.

DOI: 10.1073 /pnas. 1220766110

Mehes-Smith, M., K.K. Nkongolo, R. Narendrula and E. Cholewa, 2013. Mobility of heavy metals in plants and soil: A case study from a mining region in Canada. Am. J. Environ. Sci., 9: 483-493.

DOI: 10.3844/ajessp.2013.483.493

Mengoni, A., C. Gonnelli, H.W.J. Hakvoort, F. Galardi and M. Bazzicalupo et al., 2003. Evolution of copper-tolerance and increased expression of a $2 b$ type metallothionein gene in Silene paradoxa L. populations. Plant Soil, 257: 451-457.

DOI: $10.1023 / \mathrm{A}: 1027325907996$

Narendrula, R., K. Nkongolo and P. Beckett, 2012. Comparative soil metal analyses in sudbury (Ontario, Canada) and Lubumbashi (Katanga, DRCongo). Bull. Environ. Contamination Toxicol., 88: 187-192. DOI: 10.1007/s00128-011-0485-7

Narendrula, R., K.K. Nkongolo, P. Beckett and G. Spiers, 2013. Total and bioavailable metals in two contrasting mining regions (Sudbury in Canada and Lubumbashi in DR-Congo): Relation to genetic variation in plant populations. Chem. Ecol., 29: 111-127. DOI: 10.1080/02757540.2012.696617

Nkongolo, K.K., G. Spiers, P. Beckett, R. Narendrula and G. Theriault et al., 2013. Long-term effects of liming on soil chemistry in stable and eroded upland areas in a mining region. Water Air Soil Pollut., 224: 1-14. DOI: 10.1007/s11270-013-1618-x

Pätsikkä, E., M. Kairavuo, F. Šeršen, E.M. Aro and E. Tyystjärvi, 2002. Excess copper predisposes photosystem II to photoinhibition in vivo by outcompeting iron and causing decrease in leaf chlorophyll. Plant Physiol., 129: 1359-1367. DOI: $10.1104 /$ pp.004788

Raven, J.A., M.C.W. Evans and R.E. Korb, 1999. The role of trace metals in photosynthetic electron transport in O2-evolving organisms. Photosynthesis Res., 60: 111-150. DOI: 10.1023/A:1006282714942

Rea, P.A., 1999. MRP subfamily ABC transporters from plants and yeast. J. Experimental Botany, 50: 895-913. DOI: $10.1093 / \mathrm{jxb} / 50$. Special_Issue. 895

Ryan, P.R., H. Raman, S. Gupta, W.J. Horst and E. Delhaize, 2009. A second mechanism for aluminum resistance in wheat relies on the constitutive efflux of citrate from roots. Plant Physiol., 149: 340-351. DOI: $10.1104 /$ pp.108.129155 
Salin, M.L., 1988. Toxic oxygen species and protective systems of the chloroplast. Physiol. Plantarum, 72: 681-689. DOI: 10.1111/j.1399-3054.1988.tb09182.x

Sancenón, V., S. Puig, H. Mira, D.J. Thiele and L. Peñarrubia, 2003. Identification of a copper transporter family in Arabidopsis thaliana. Plant Molecular Biol., 51: 577-587.

DOI: $10.1023 / \mathrm{A}: 1022345507112$

Scandalios, J.G., 1993. Oxygen stress and superoxide dismutases. Plant Physiol., 101: 7-12. DOI: $10.1104 / p p .101 .1 .7$

Shahbaz, M., M.H. Tseng, C.E.E. Stuiver, A. Koralewska and F.S. Posthumus et al., 2010. Copper exposure interferes with the regulation of the uptake, distribution and metabolism of sulfate in Chinese cabbage. J. Plant Physiol., 167: 438-446.

DOI: $10.1016 /$ j.jplph.2009.10.016

Theriault, G. and K. Nkongolo, 2016. Nickel and copper toxicity and plant response mechanisms in white birch (Betula papyrifera). Bull. Enviro. Contamination Toxicol., 97: 171-176. DOI: $10.1007 / \mathrm{s} 00128-016-1842-3$

Theriault, G., K.K. Nkongolo and P. Michael, 2014. Genetic and metal analyses of fragmented populations of Betula papyrifera (Marsh) in a mining reclaimed region: Identification of population-diagnostic molecular marker. Ecol. Evolution, 4: 3435-3443. DOI: 10.1002/ece3.1195

Tran, A., K.K. Nkongolo, M. Mehes-Smith, R. Narendrula and G. Spiers et al., 2014. Heavy metal analysis in red oak (Quercus rubra) populations from a mining region in northern Ontario (Canada): Effect of soil liming and analysis of genetic variation. Am. J. Environ. Sci., 10: 363-373.

DOI: 10.3844 /ajessp.2014.363.373
Van Hoof, N.A., V.H. Hassinen, H.W. Hakvoort, K.F. Ballintijn and H. Schat et al., 2001. Enhanced copper tolerance in Silene vulgaris (Moench) garcke populations from copper mines is associated with increased transcript levels of a 2b-type metallothionein gene. Plant Physiol., 126: 1519-1526.

DOI: $10.1104 /$ pp. 126.4 .1519

Violante, A., V. Cozzolino, L. Perelomov, A. Caporale and M. Pigna, 2010. Mobility and bioavailability of heavy metals and metalloids in soil environments. J. Soil Sci. Plant Nutrition, 10: 268-292. DOI: $10.4067 / \mathrm{S} 0718-95162010000100005$

Winterhalder, K., 1995. Early History of human Activities in the Sudbury Area and Ecological Damage to the Landscape. In: Restoration and Recovery of an Industrial Region, Gunn, J.M. (Ed.), New York: Springer-Verlag New York, pp: 17-31.

Woeste, K.E. and J.J. Kieber, 2000. A strong loss-offunction mutation in RAN1 results in constitutive activation of the ethylene response pathway as well as a rosette-lethal phenotype. Plant Cell, 12: 443-455. DOI: $10.2307 / 3870948$

Wuana, R.A. and F.E. Okieimen, 2011. Heavy metals in contaminated soils: A review of sources, chemistry, risks and best available strategies for remediation. ISRN Ecol., 2011: 1-21. DOI: 10.5402/2011/402647

Yadav, S.K., 2010. Heavy metals toxicity in plants: An overview on the role of glutathione and phytochelatins in heavy metal stress tolerance of plants. South African J. Botany, 76: 167-179. DOI: 10.1016/j.sajb.2009.10.007

Yruela, I., 2005. Copper in plants. Brazilian J. Plant Physiol., 17: 145-156. DOI: $10.1590 / \mathrm{S} 1677-04202005000100012$

Yruela, I., 2009. Copper in plants: Acquisition, transport and interactions. Functional Plant Biol., 36: 409-430. DOI: 10.1071/FP08288 